\title{
Lupus nephritis: current update
}

\author{
Ramesh Saxena*, Tina Mahajan and Chandra Mohan*
}

\begin{abstract}
Lupus nephritis is a major cause of morbidity and mortality in patients with systemic lupus erythematosus. The general consensus is that $60 \%$ of lupus patients will develop clinically relevant nephritis at some time in the course of their illness. Prompt recognition and treatment of renal disease is important, as early response to therapy is correlated with better outcome. The present review summarizes our current understanding of the pathogenic mechanisms underlying lupus nephritis and how the disease is currently diagnosed and treated.
\end{abstract}

\section{Introduction}

Lupus nephritis (LN) is a major cause of morbidity and mortality in patients with systemic lupus erythematosus (SLE). The general consensus is that $60 \%$ of lupus patients will develop clinically relevant nephritis at some time in the course of their illness [1]. Prompt recognition and treatment of renal disease is important, as early response to therapy is correlated with better outcome [2]. The present review summarizes our current understanding of SLE pathogenesis, summarizes how the disease is diagnosed and treated, and expands on new emerging therapies.

\section{Epidemiology of lupus nephritis}

Most SLE patients develop nephritis early in the course of their disease. The vast majority of patients who develop nephritis are younger than 55 years, and children are more likely to develop severe nephritis than are elderly patients [3]. In a recent retrospective study, male sex, young age ( $<33$ years), and non-European ancestry were found to be determinants of earlier renal disease in patients with SLE. Asian, African Caribbean, and African American ethnicities may present with more severe nephritis than other ethnic groups [4].

*Correspondence: Ramesh.saxena@utsouthwestern.edu;

Chandra.mohan@utsouthwestern.edu

Department of Internal Medicine, UT Southwestern Medical Center,

5323 Harry Hines Boulevard, Dallas, TX 75390, USA

\section{Diagnosis of lupus nephritis}

\section{Clinical features of lupus nephritis}

Proteinuria is the characteristic feature of renal disease in lupus. In a comprehensive review of LN, proteinuria was reported in $100 \%$ of patients, with nephrotic syndrome being reported in 45 to $65 \%$ [5]. Microscopic hematuria was found to occur in about $80 \%$ of patients during the disease course, invariably associated with proteinuria. Macroscopic hematuria is rare in LN. Hypertension is not common but is present more frequently in patients with severe nephritis. About one-half of all patients with LN will have a reduced glomerular filtration rate, and occasionally patients present with acute kidney injury. Renal tubular function is often disturbed, resulting in urinary excretion of Tamm-Horsefall proteins, light chains and $\beta_{2}$-microglobulin [5].

\section{Clinical diagnosis of lupus nephritis}

Ideally, urinary protein excretion is gauged using a 24-hour urine collection. Although universally practiced, variable results may occur over a short period of time, probably due to changes in physical activity or collection errors. The latter problem can be remedied by quantifying total creatinine in the same 24-hour urine collection. The total creatinine measurement should approximate values obtained in 24-hour urine collections from the same patient and should be comparable with average values obtained in population studies of men $(20 \mathrm{mg} / \mathrm{kg} /$ day) and women $(15 \mathrm{mg} / \mathrm{kg} /$ day). Alternatively, the urinary protein excretion rate can be estimated by assaying the protein/creatinine ratio in a random daytime urinary sample. This ratio approximates the total number of grams per day of proteinuria, but it would be optimal to confirm the validity of this method in individual patients, as described [5].

The urinary sediment is also useful for characterizing renal disease activity, since the presence of hematuria, leukocyturia or casts are typical only during periods of disease activity. Interestingly, in one large series of 520 cases of SLE, red cell casts were only present in 39 cases ( $7.5 \%$ of patients). In descending order, the most common abnormal urinary sediment findings in LN are leukocyturia, hematuria, granular casts and hyaline casts [6].

A rising anti-DNA antibody titer and hypo-complementemia, especially with low complement C3, are 
strong indicators of active lupus renal disease, although serology cannot be used in isolation to diagnose or monitor renal disease. Hypo-albuminemia accompanied by significant proteinuria is a component of the nephrotic syndrome that may accompany active lupus renal disease. Hypercholesterolemia is another marker and also a clinical complication of the nephrotic syndrome that can accompany active LN [5].

There is increasing recognition of the importance of tubulointerstitial injury in LN. In the majority of patients, the severity of interstitial inflammation parallels the degree of involvement of the glomerulus. Tubular damage, fibrosis and atrophy can be associated with hyperuricemia and renal tubular acidosis [5].

\section{Histologic diagnosis of lupus nephritis}

Kidney biopsy is the mainstay for the diagnosis of LN. Material obtained by renal biopsy is evaluated by light microscopy, immunofluorescence and electron microscopy. In many cases, renal biopsy is instrumental in establishing the diagnosis of SLE because nephritis can be the first clinical manifestation of SLE in up to 15 to $20 \%$ of patients [5]. In the majority of cases, however, the diagnosis of SLE is already established. In such situations, renal biopsy helps to establish a precise diagnosis of LN, the extent of histopathological chronicity and activity, disease prognosis, and also serves as a guide for therapy. The appearance of any new markers of kidney disease such as proteinuria, hematuria, active urinary sediment or rise in serum creatinine in a SLE patient should also prompt a renal biopsy. Moreover, one should consider a follow-up biopsy in a stable patient with established LN if the aforesaid markers reappear or worsen.

\section{Histologic classification of lupus nephritis}

Because of the extremely diverse histopathology of LN, several classifications have been proposed over the past four decades - the earliest schemes being proposed by the World Health Organization (WHO) in 1974, further refined by Austin and colleagues [7,8]. In order to further standardize definitions and to facilitate uniformity in reporting, as well as to eliminate ambiguities and inconsistencies in the WHO classification, the International Society of Nephrology/Renal Pathology Society (ISN/ RPS) classification was formulated in 2003, as detailed in Table 1 [9]. This classification defines more precisely all glomerulonephritis (GN) classes and clearly delineates activity and chronicity.

Two recent studies demonstrate the superior reproducibility of the ISN/RPS classification compared with the WHO classification of LN $[10,11]$. In a large study involving 20 centers in the UK, renal pathologists classified cases of LN using the WHO system and then reclassified the same cases using the ISN/RPS 2003
Table 1. International Society of Nephrology/Renal Pathology Society classification of lupus nephritis

\begin{tabular}{cl}
\hline Class I & Minimal mesangial lupus nephritis \\
Class II & Mesangial proliferative lupus nephritis \\
Class III & Focal lupus nephritis (<50\% glomeruli) \\
III(A) & Active lesions \\
III(A/C) & Active and chronic lesions \\
III(C) & Chronic lesions \\
Class IV & Diffuse lupus nephritis (>50\% glomeruli) \\
& Diffuse segmental (IV-S) or global (IV-G) \\
IV(A) & Active lesions \\
IV(A/C) & Active and chronic lesions \\
IV(C) & Chronic lesions \\
Class V & Membranous lupus nephritis \\
Class VI & Advanced sclerosing lupus nephritis \\
& ( $\geq 90 \%$ globally sclerosed glomeruli without residual activity) \\
\hline
\end{tabular}

Adapted with premission from Weening et al. [9].

classification scheme one year later. A significantly higher interobserver reproducibility was observed using the ISN/RPS (2003) classification than using the modified WHO (1982) classification [10].

\section{Pathogenesis of lupus nephritis}

Multiple mechanisms lead to $\mathrm{LN}$, as reviewed elsewhere [12-14]. The pathogenic events leading to LN can be parsed into two phases: systemic events in the immune system, and local events in the end organs (see Figure 1). The present review focuses on the cellular and molecular mechanisms that drive LN pathogenesis within the kidneys. Systemic events that orchestrate autoimmunity in SLE have been discussed in previous reviews [12-14], and will not be examined here.

\section{Role of lymphocytes in lupus nephritis}

$\mathrm{T}$ cells rank among the most conspicuous inflammatory cells within the inflamed kidney in both SLE patients and mouse models of LN $[15,16]$. T cells cloned from the renal interstitium of MRL/lpr lupus mice have been shown to be autoreactive to renal antigens, to induce tubular epithelial and mesangial cell proliferation, and to produce cytokines such as IFNy. The pathogenic role of $\mathrm{T}$ cells within the kidneys has been demonstrated through the use of renal transplantation in MHC II-deficient or $\mathrm{CD} 4^{-1-}$ lupus-prone mice and treatment with anti-CD4 antibody [17-20]. Radeke and colleagues have demonstrated that $\mathrm{CD} 4^{+} \mathrm{T}$ cells alone were sufficient as initiators and effectors in nephritis, by recognizing specific antigens expressed within the glomeruli in an experimental mouse model of GN [21]. Although the antigen specificity of intrarenal T cells in LN remains elusive, their effector 


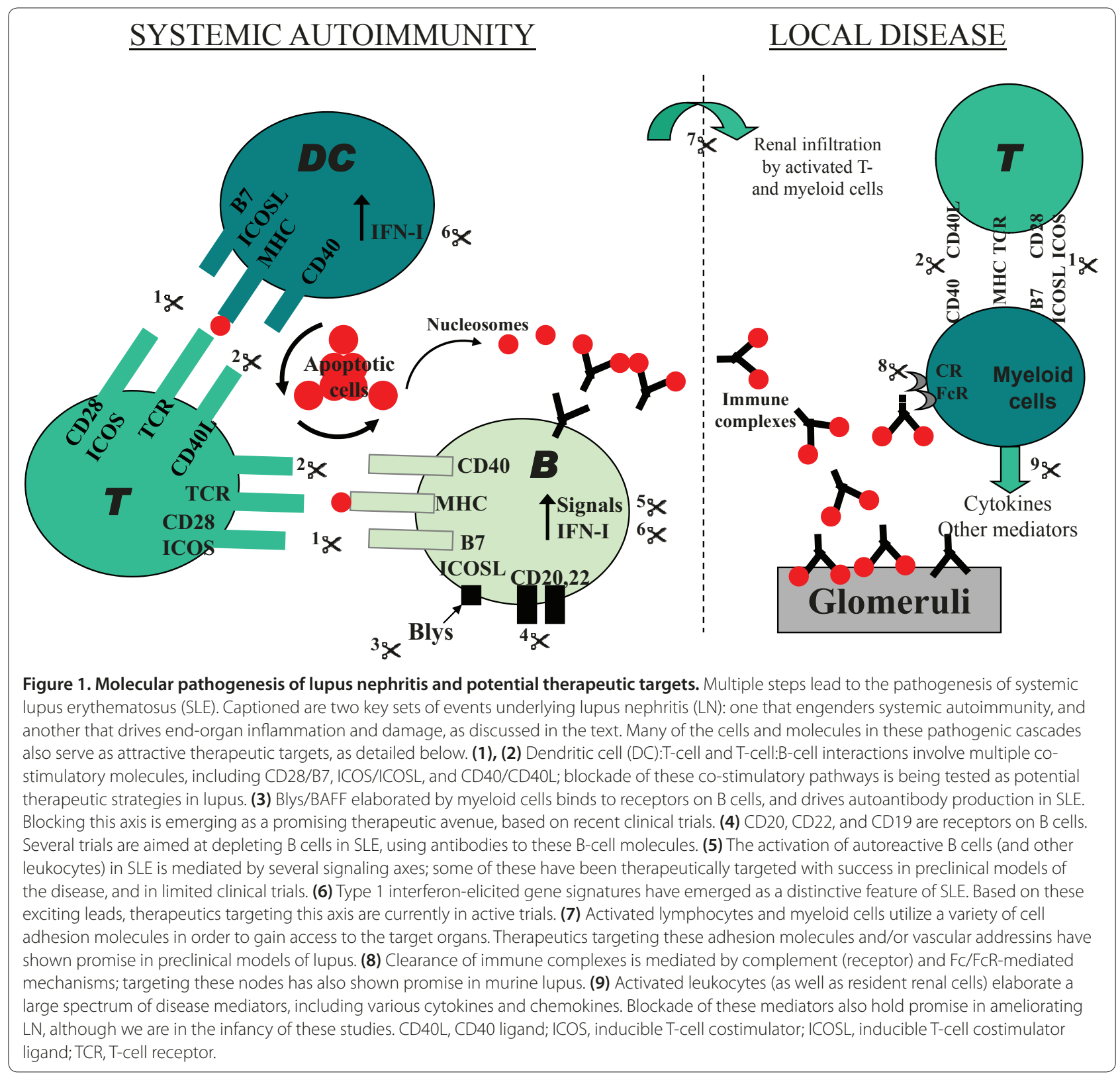

function has been shown to be mediated through a couple of key cell-surface molecules and released cytokines.

Substantial evidence has been garnered for the pathogenic role of CD40 ligand (CD40L), a member of the TNF family [21-26]. The interaction of T-cell CD40L and CD40 expressed on B cells plays a central role in humoral immune responses, having the capacity to induce clonal expansion, immunoglobulin class switch and differentiation of B cells into plasma cells. In addition, CD40 is expressed on various effectors cells, such as macrophages, neutrophils, dendritic cells (DCs), as well as resident renal cells, suggesting that $\mathrm{CD} 40-\mathrm{CD} 40 \mathrm{~L}$ interactions may be important in driving effector functions of other
CD40-expressing cells within the kidneys [27-31]. CD40 expression is markedly upregulated in proliferative lupus nephritis (PLN), in parallel with the increased presence of CD40L-bearing $\mathrm{T}$ cells in kidneys [29]. Activated $\mathrm{T}$ cells co-cultured with renal tubular epithelial cell elaborate high levels of monocyte chemotactic protein-1, RANTES, IL-8 and interferon-inducible protein-10 from tubular epithelial cells, mediated in part through CD40CD40L interactions [30,31].

Among the cytokines released by $\mathrm{T}$ cells, a predominance of T-helper type 1 response has been documented by several studies in human LN [32-36], further supported by blocking (or gene ablation) studies in 
murine LN [37-40]. However, there is also some evidence that T-helper type 2 cytokines can also have a potential impact on LN. In several lupus-prone mouse models, engineering the upregulation of IL- 4 worsens LN, whereas IL-4 blockade or gene ablation ameliorates disease [4144]. Given that IL-4 has also been implicated in fibroblast proliferation, collagen gene expression, collagen synthesis and transforming growth factor beta (TGF $\beta$ ) production, IL-4 may directly act upon renal cells to perpetuate glomerulosclerosis and chronic renal fibrosis, partly through its effect on extracellular matrix generation [44].

\section{Role of myeloid cells in lupus nephritis}

Besides lymphocytes, myeloid cells also play critical roles in LN. Within normal human kidneys, at least two myeloid DC subtypes characterized by BDCA-1 ${ }^{+}$DC$\mathrm{SIGN}^{+}$and BDCA-1 ${ }^{+} \mathrm{DC}-\mathrm{SIGN}^{-}$and one plasmacytoid DC subtype defined as BDCA-2 ${ }^{+} \mathrm{DC}-\mathrm{SIGN}^{-}$are abundantly located in the tubulointerstitium, but are rarely observed within the glomeruli [45-47]. In LN patients, strong renal infiltrates of $\mathrm{BDCA}^{+}, \mathrm{BDCA}^{+}$and $\mathrm{BDCA} 4^{+}$ DCs have been reported. Notably, DCs infiltrated both the tubulointerstitium and the glomeruli, with the extent of infiltration correlating well with the severity of renal damage, notably class III/IV LN $[48,49]$. As in normal kidneys, DC infiltrates in diseased human kidneys were mostly immature, marked by the absence of DC-LAMP ${ }^{+}$ cells $[45,48]$. In contrast to the renal DCs, a significant decrease of myeloid DCs and/or plasmacytoid DCs has been observed in the peripheral blood of lupus patients [48-51]. It has been suggested that the decreased number of DCs in peripheral blood may be a consequence of their enhanced migration into the end organs [49,52]. Studies in murine models have also reported increased infiltration of DCs into the renal glomeruli and tubulointerstitium [53-56]. Relatively little is known about how renal infiltrating DCs contribute to the pathogenesis of LN, although a couple of scenarios have been suggested. First, DCs may elaborate proinflammatory and profibrotic factors, including TNF $\alpha$, IL-6, IL-1, IL-18, IFN $\alpha$ and TGF $\beta$ [57]. Second, DCs can migrate to local lymph nodes and potentially present renal autoantigens to $\mathrm{T}$ lymphocytes [58]. Third, since renal DCs express various co-stimulatory molecules such as CD40L, MHC II and chemokine receptors such as CCR1 and CCR5, they could directly interact with and activate intrinsic renal cells and other infiltrating inflammatory cells, hence perpetuating disease [58-60].

Macrophages represent a second myeloid cell type that is recruited to the kidneys in LN [54,61-63]. Recruited macrophages are located in both the glomerular tuft and tubulointerstitium, and constitute the major cell type in glomerular crescents [61-64]. Renal infiltrating macrophages exhibit elevated expression of CD11b, OX40L,
CD80 and CD86, being markers of disease onset in LN. Once recruited, activated macrophages could play a wide variety of roles in meditating renal injury, largely by secreting various proinflammatory mediators (including TNF and IL-1), reactive oxygen species and proteolytic enzymes. Although the obligatory role for macrophages has been demonstrated in experimental GN models [65-68], whether they are equally essential for LN remains unknown.

\section{Role of resident renal cells in lupus nephritis}

The major resident cells in the kidney include mesangial cells, endothelial cells and epithelial cells. These intrinsic renal cells represent both the cause and the victim of various insults leading to GN $[69,70]$. Perhaps the most compelling evidence that intrinsic renal cells play an important role in immune-meditated GN has come from bone-marrow transfer or kidney-transplant studies in mice subjected to anti-glomerular basement membrane nephritis. Studies of this nature have helped outline the disease role of MHC II, TNF and Fn14 on intrinsic renal cells [71-73].

Beside these isolated examples, we know very little about whether other molecules need to be intrinsically expressed within resident renal cells in order for immune-mediated GN to ensue. Some studies have suggested that resident renal cells from lupus-prone mice are intrinsically aberrant; for example, it has been reported that mesangial cells from lupus mice have a decreased threshold for the production of inflammatory mediators, and do indeed elaborate more monocyte chemotactic protein-1 and osteopontin [74-76]. We currently have no insights into whether intrinsic renal cells may be fundamentally different in human LN compared with what we know about the role of infiltrating leukocytes in LN. Therefore, our understanding of how intrinsic renal cells contribute to disease is rudimentary.

\section{Role of cytokines and chemokines in lupus nephritis}

As alluded to above, cytokines have emerged as important players in the pathogenesis of LN. Whereas some cytokines that aggravate LN may act predominantly in a systemic fashion (for example, BAFF), other cytokines such as IL-17, IFN $\alpha$ and TGF $\beta$ have been shown to have a role in systemic autoimmunity as well as local renal disease. Increased IL-17-producing $\mathrm{T}$ cells have been documented within the kidneys in both SLE patients and SNF1 lupus-prone mice, with disease treatment being associated with reduced numbers of these cells $[77,78]$. Several independent experiments have found peripheral blood mononuclear cells from SLE patients to exhibit a prominent type I interferon-inducible gene expression profile, referred to as the interferon signature, supporting 
the hypothesis that type I interferons may play a key role in lupus pathogenesis [79-81]. Although IFN-I is known to impact systemic immunity in a variety of ways, recent evidence indicates that IFN-I produced by resident renal cells may be also contribute to renal inflammation [82].

TGF $\beta$ is a potent multifunctional cytokine that exerts an anti-inflammatory and immunosuppressive role systemically, but a profibrotic role locally within diseased kidneys. The action of persistent, dysregulated TGF $\beta$ production on the extracellular matrix drives progressive renal disease in LN [83]. Elevated TGF $\beta$ expression has been found in SLE renal tissue, correlating well with histological activity [84-86]. Also, disease remission in $\mathrm{LN}$ is related to decreased renal TGF $\beta$ expression [85]. The collective data in the field strongly indicate that reduced TGF $\beta$ in immune cells predisposes mice to immune dysregulation and autoantibody production, whereas enhanced TGF $\beta$ expression within the kidneys leads to dysregulated tissue repair, progressive fibrogenesis and eventual end-organ damage [87]. Hence, TGF $\beta$ is a double-edged sword - subduing systemic immunity, but aggravating chronic nephritis.

As discussed above, macrophages play a central role in mediating LN. Hence, not surprisingly, colony-stimulating factor-1 (CSF-1, the principal macrophage growth factor) and macrophage migration inhibitory factor - key proinflammatory cytokines regulating macrophage recruitment - have also been documented as central players in LN. Renal resident cells, most notably tubular epithelial cells, are the primary source of CSF-1 during renal disease $[88,89]$. Increased renal expression of CSF-1 has been noted before overt renal pathology and becomes more abundant with advancing LN [90]. Mechanistic studies in murine models have garnered direct experimental support for a pathogenic role of CSF-1 and migration inhibitory factor in LN [91-98]. Other cytokines that have been shown to be important for antibody-mediated renal disease and/or LN include IL-1, IL-6, IL-10 and TNF $\alpha$, as reviewed elsewhere [99]. Besides cytokines, a pathogenic role has also been assigned to two chemokines - monocyte chemotactic protein-1 and CXCL12. Both chemokines are elevated within diseased kidneys in mice and patients with LN, while mechanistic studies in mice support their role in disease pathogenesis [100-113].

Since most of the above cytokines and chemokines can be elaborated systemically as well as locally within the kidneys, it remains to be established whether renal expression of any of these molecules is necessary for LN. The complex pathogenic cascades leading to SLE lend themselves to therapeutic intervention at multiple nodes, some systemic and some intrarenal, some of which are discussed in Figure 1. Several of the indicated therapeutic strategies have only been tried in preclinical models of LN, whereas others are currently in active clinical trials, as discussed below. As we gain better insights into these molecular cascades and their druggability, the goal is to eventually identify the optimal combinatorial regimes that could potentially silence all critical pathways leading to disease.

\section{Treatment of lupus nephritis}

Before the advent of immunosuppressive regimens, a 2 -year survival rate $<10 \%$ was observed in patients with diffuse PLN treated with low-dose steroids [114]. Since then, the survival of patients with PLN has improved considerably due to earlier recognition of renal disease, aggressive immunosuppression and improved supportive care [115]. Numerous prognostic factors have been identified in LN. Among others, nonwhite race (for example, black, Afro-Caribbean, Hispanic), poor socioeconomic status, uncontrolled hypertension, a high activity and chronicity index on kidney biopsy, renal impairment at baseline, poor initial response to therapy and nephritic relapses have been associated with poor outcome. Lack of adherence to therapy is an underestimated cause of treatment failure $[116,117]$. The therapeutic goals for a patient with newly diagnosed LN are to achieve prompt renal remission using induction therapy, to avoid renal flares and chronic renal impairment using maintenance therapy, and to minimize treatment-associated toxicity. These goals are discussed further below.

\section{Induction therapy with intravenous cyclophosphamide}

In 1986, Austin and colleagues from the National Institutes of Health (NIH) published the results of a large randomized trial demonstrating the role of intravenous (i.v.) cyclophosphamide (CYC) as an induction therapy, as listed in Table 2 [118]. In a later NIH trial, combination therapy of i.v. methylprednisolone and i.v. CYC was shown to achieve a higher rate of renal remission than i.v. methylprednisolone alone [119]. After a median followup of 11 years, none of the 20 patients who received combination therapy experienced end-stage renal disease (ESRD). Despite excellent efficacy, i.v. CYC treatment is associated with a high rate of premature ovarian failure (ranging from 38 to $52 \%$ of women at risk), increased risk of severe infections, a significant percentage of treatment failures and a high rate of renal relapse [120].

In order to reduce total CYC exposure and toxicity, low-dose intermittent i.v. CYC was next investigated. The Euro-Lupus Nephritis Trial compared a NIH-like highdose regimen of i.v. CYC (six monthly pulses followed by two quarterly pulses) with the Euro-Lupus low-dose regimen (six pulses of i.v. CYC every 2 weeks at a fixed dose of $500 \mathrm{mg}$ ) [121]. The rates of renal remission were not statistically different between the two groups, but treatment-related adverse effects were less frequent with the reduced-dose regimen. Limitations of the EuroLupus trial include a population with relatively milder 
Table 2. Randomized controlled studies in lupus nephritis

\begin{tabular}{|c|c|c|c|c|c|}
\hline $\begin{array}{l}\text { Drug and } \\
\text { reference }\end{array}$ & Description & Primary endpoint & $\begin{array}{l}\text { Number and } \\
\text { type of patients }\end{array}$ & $\begin{array}{l}\text { Follow-up } \\
\text { duration }\end{array}$ & Results \\
\hline CYC [118] & $\begin{array}{l}\text { Patients randomized to i.v. } \\
\text { CYC vs. p.o. CYC, p.o. CYC + } \\
\text { AZA, AZA, or prednisone }\end{array}$ & Time to kidney failure & $\begin{array}{l}n=107, \text { mainly class III } \\
\text { and IV LN }\end{array}$ & 7 years & $\begin{array}{l}\text { Time to ESRD is significantly } \\
\text { longer in patients receiving } \\
\text { i.v. CYC compared with those } \\
\text { receiving steroids alone }\end{array}$ \\
\hline CYC [121] & $\begin{array}{l}\text { Patients randomized to high- } \\
\text { dose }(500 \text { to } \\
\left.1,000 \mathrm{mg} / \mathrm{m}^{2}\right) \text { monthly i.v. } \\
\text { CYC for } 6 \text { months vs. low- } \\
\text { dose i.v. CYC regimen } 500 \mathrm{mg} \\
\text { every } 2 \text { weeks } x \text { six doses }\end{array}$ & $\begin{array}{l}\text { Treatment failure } \\
\text { (doubling of sCr, } \\
\text { absence of primary } \\
\text { response or occurrence } \\
\text { of a flare) }\end{array}$ & $\begin{array}{l}n=90, \text { class IV LN, } 85 \% \\
\text { Caucasian }\end{array}$ & 41 months & $\begin{array}{l}\text { Induction therapy with low- } \\
\text { dose CYC is as effective as } \\
\text { high-dose CYC }\end{array}$ \\
\hline MMF [123] & $\begin{array}{l}\text { Patients randomized to } \\
6 \text { months induction with } \\
\text { MMF ( } 2 \mathrm{~g} / \text { day) or oral } \\
\text { CYC ( } 2.5 \mathrm{mg} / \mathrm{kg} / \text { day })+ \\
\text { prednisolone }\end{array}$ & $\begin{array}{l}\text { Incidence of complete } \\
\text { remission }\end{array}$ & $\begin{array}{l}n=42, \text { class IV LN, } 100 \% \\
\text { Chinese }\end{array}$ & 12 months & $\begin{array}{l}\text { Induction therapy with MMF is } \\
\text { as effective as oral CYC }\end{array}$ \\
\hline MMF [124] & $\begin{array}{l}\text { Patients randomized to } \\
\text { monthly i.v. CYC or MMF } \\
\text { ( } 3 \mathrm{~g} / \text { day) }\end{array}$ & $\begin{array}{l}\text { Incidence of complete } \\
\text { remission at } 6 \text { months }\end{array}$ & $\begin{array}{l}n=140 \text {, class IV, } 56 \% \\
\text { African American }\end{array}$ & 6 months & $\begin{array}{l}\text { MMF was not inferior to i.v. CYC } \\
\text { for induction of remission. In } \\
\text { fact, MMF was more effective } \\
\text { and better tolerated than i.v. } \\
\text { CYC at inducing remission }\end{array}$ \\
\hline MMF [125] & $\begin{array}{l}\text { Patients randomized to } \\
\text { MMF or monthly i.v. CYC for } \\
\text { induction }\end{array}$ & $\begin{array}{l}\text { Prespecified decrease in } \\
\text { urine protein/creatinine } \\
\text { ratio and improvement } \\
\text { in } \mathrm{sCr}\end{array}$ & $\begin{array}{l}n=370, \text { classes III to } V \\
L N, 75 \% \text { Caucasian }\end{array}$ & 6 months & $\begin{array}{l}\text { MMF is not superior to i.v. } \\
\text { CYC as induction therapy. } \\
\text { No significant differences in } \\
\text { response rate between the two } \\
\text { groups. Adverse events were } \\
\text { similar }\end{array}$ \\
\hline MMF [126] & $\begin{array}{l}\text { Patients randomized to } \\
\text { quarterly i.v. CYC, MMF, or } \\
\text { AZA for maintenance after } \\
\text { induction with i.v. CYC }\end{array}$ & $\begin{array}{l}\text { Incidence of patient and } \\
\text { kidney survival }\end{array}$ & $\begin{array}{l}n=59 \text {, classes III and IV } \\
\mathrm{LN} \text {, African American } \\
\text { and Hispanic }\end{array}$ & 72 months & $\begin{array}{l}\text { MMF and AZA are both } \\
\text { efficacious and safer than i.v. } \\
\text { CYC for maintenance therapy }\end{array}$ \\
\hline AZA [126] & $\begin{array}{l}\text { Patients randomized to } \\
\text { quarterly i.v. CYC, MMF, or } \\
\text { AZA for maintenance after } \\
\text { induction with i.v. CYC }\end{array}$ & $\begin{array}{l}\text { Incidence of patient and } \\
\text { kidney survival }\end{array}$ & $\begin{array}{l}n=59 \text {, classes III and IV } \\
L N \text {, African American } \\
\text { and Hispanic }\end{array}$ & 72 months & $\begin{array}{l}\text { MMF and AZA are both } \\
\text { efficacious and safer than i.v. } \\
\text { CYC for maintenance therapy }\end{array}$ \\
\hline $\begin{array}{l}\text { AZA, MMF (Houssiau } \\
\text { and colleagues, } \\
\text { 2010) }\end{array}$ & $\begin{array}{l}\text { Patients randomized to MMF, } \\
\text { or AZA for maintenance after } \\
\text { induction with low-dose } \\
\text { i.v. CYC }\end{array}$ & Time to renal flares & $\begin{array}{l}n=103 \text {, classes III and IV } \\
L N \text {, European }\end{array}$ & Minimum 3 years & $\begin{array}{l}\text { No significant difference in renal } \\
\text { flares with MMF and AZA as } \\
\text { maintenance therapy }\end{array}$ \\
\hline $\begin{array}{l}\text { Rituximab (Rovin } \\
\text { and colleagues, } \\
\text { 2009) }\end{array}$ & $\begin{array}{l}\text { Patients randomized to } \\
\text { MMF or MMF + rituximab for } \\
\text { induction therapy }\end{array}$ & $\begin{array}{l}\text { Incidence of complete } \\
\text { or partial renal remission }\end{array}$ & $\begin{array}{l}n=144 \text {, classes III and } \\
\text { IV LN }\end{array}$ & 52 weeks & $\begin{array}{l}\text { Rituximab does not have an } \\
\text { additive benefit to MMF for } \\
\text { induction therapy }\end{array}$ \\
\hline
\end{tabular}

AZA, azathioprine; CYC, cyclophosphamide; ESRD, end-stage renal disease; i.v., intravenous; LN, lupus nephritis; MMF, mycophenolate mofetil; p.o., oral; sCr, serum creatinine.

renal disease (mean creatinine 1 to $1.3 \mathrm{mg} / \mathrm{dl}$; mean proteinuria 2.5 to $3.5 \mathrm{~g}$ /day for both groups), with almost $85 \%$ of the patients being Caucasian. Nevertheless, lowdose i.v. CYC is an option - particularly for low-risk Caucasians with less severe PLN.

\section{Noncyclophosphamide induction regimens: mycophenolate mofetil}

Recently, mycophenolate mofetil (MMF) has emerged as a promising alternative therapy for both induction and maintenance treatment of LN. Mycophenolic acid, the active metabolite of MMF, is an inhibitor of the ratelimiting enzyme (inosine monophosphate dehydrogenase) involved in de novo purine synthesis [122]. As lymphocytes do not possess a salvage pathway for the generation of these nucleotides, MMF results in selective blockade of Bcell and T-cell proliferation. Unlike CYC, mycophenolic acid has little impact on other tissues with high proliferative activity (for example, neutrophils, skin, intestine, bone marrow, gonads), which do possess a salvage pathway for nucleotide synthesis. This accounts for the metabolite's more favorable toxicity profile compared with CYC, and this renders MMF particularly attractive.

As listed in Table 2, Chan and colleagues randomized 42 patients with PLN to 6 months of induction with MMF (2 g/day) or oral CYC $(2.5 \mathrm{mg} / \mathrm{kg} /$ day $)$, both with concurrent oral prednisolone [123]. During the maintenance phase, those patients in the MMF arm continued the drug at a reduced dose ( $1 \mathrm{~g} /$ day $)$ and those in the CYC arm switched to azathioprine (AZA) $(1.5 \mathrm{mg} / \mathrm{kg} /$ 
day) for 6 months. This study suggested that induction treatment with MMF was as effective as oral CYC, but with fewer side effects. Although this study included only Chinese patients and excluded patients with poor prognostic indicators, a more recent study has demonstrated the increased efficacy of MMF induction in a high-risk, multiracial, American population in which $56 \%$ of the patients were African American [124] (Table 2). Limitations of the latter study included its short follow-up duration, the crossover design and the fact that patients with rapidly progressive renal failure were excluded.

Later on, another US study, the Aspreva Lupus Management Study, comprising high risk population with proliferative LN demonstrated similar efficacies of MMF and intravenous CYC as induction therapies [125] (Table 2). Furthermore, it was observed that, race, ethnicity and geographical region may affect treatment response; more Black and Hispanic patients responded to MMF than i.v. CYC. As the study was not designed for this sub-group analysis, it is difficult to draw firm conclusions about their importance.

\section{Maintenance therapies}

Once a patient has attained remission, immunosuppression is given to help maintain remission, to prevent relapse, and to decrease the risk of developing ESRD. In the NIH trials, i.v. CYC at 3-month intervals for 18 to 24 months was used as maintenance therapy [118]. In the past decade, sequential regimens of short-term CYC induction therapy, followed either by MMF or AZA maintenance, have proven to be efficacious and safe, with reduced hazards, compared with long-term exposure to CYC. Using a similar regime, Contreras and colleagues have reported similar findings in a randomized controlled study that included a large number of high-risk nonCaucasian patients, predominantly African Americans and Hispanics [126] (Table 2). In a recently concluded Euro-Lupus Nephritis Trial multi-center trial (MAINTAIN Nephritis Trial) comprising 105 patient with proliferative LN, no significant difference in renal flares was observed between AZA and MMF as maintenance therapy over 3 years of follow up [127].

Another trial comparing MMF against AZA as remission-maintaining treatment for PLN following induction with a short course of intravenous CYC, the maintenance phase of the Aspreva Lupus Management Study [125], has recently been concluded and the results were presented at the American Society of Nephrology Meeting in 2010. It did not show any difference in renal flares between the two maintenance therapies (Table 3).

\section{Adjunctive therapy}

As co-morbidities can significantly worsen outcome, these have to be actively managed in LN. Accelerated atherogenesis and coronary vascular disease are now recognized complications of SLE [128]. Recognized risk factors include hypertension, hyperlipidemia, nephrotic syndrome, prolonged corticosteroid use, antiphospholipid antibody syndrome and, in some cases, the vascular risks associated with chronic kidney disease. This underscores the importance of aggressively managing these modifiable risk factors [129]. Although few data are available specifically for patients with LN, it appears prudent to apply the knowledge gleaned from studying the general population with chronic kidney disease. Tight blood pressure control, the use of angiotensin-converting enzyme inhibitors and/or angiotensin receptor blockers, and correction of dyslipidemia are thus strongly recommended. Moreover, patients with chronic kidney disease should be screened and treated for complications such as anemia and bone and mineral disease (secondary hyperparathyroidism, hyperphosphatemia, vitamin $\mathrm{D}$ deficiency). In addition, measures should be taken to prevent glucocorticoid-induced osteoporosis, including the use of calcium, vitamin D supplements, and bisphosphonates when necessary [130].

\section{Novel approaches in the treatment for PLN}

Despite recent strides in the treatment of LN, about 20\% of patients do not respond but progress to ESRD. Moreover, toxicity of the current immunosuppressive regimens remains unacceptably high. With a better understanding of the molecular mechanisms underlying LN, as discussed above (Figure 1), several newer and targeted therapeutic approaches are currently being tested, aimed at improved efficacy and reduced toxicity. These include LPJ394, rituximab, epratuzumab, belimumab, and abatacept, as summarized in Table 3. This targeted therapy constitutes another area of research that is rapidly burgeoning with ongoing contributions from academia and from industry. As ongoing efforts in transcriptomics and proteomics further elucidate the molecular basis of lupus pathogenesis, the drugs that dominate the therapeutic landscape are likely to evolve rapidly.

\section{Treatment of resistant lupus nephritis}

While there has been significant improvement in how we manage LN, up to $20 \%$ of patients with $\mathrm{LN}$ are refractory to initial induction treatment, while 30 to $50 \%$ of patients still progress to ESRD [136]. Many of these patients have poor prognostic factors including African American race, delayed initiation of treatment, poor compliance, and arterial hypertension at presentation [137]. More aggressive CYC regimens have been tried in these patients. One method involves the use of oral CYC instead of i.v. CYC. As the cumulative dose is higher in patients who receive daily oral dosing, it may be expected to be more effective 
Table 3. Novel therapeutic regimes in lupus nephritis targeting specific pathogenic molecules

\begin{tabular}{|c|c|c|c|c|}
\hline $\begin{array}{l}\text { Drug and } \\
\text { reference }\end{array}$ & $\begin{array}{l}\text { Description of } \\
\text { drug or target }\end{array}$ & Mechanism of action & Details of trial & Outcome of trial \\
\hline $\begin{array}{l}\text { LPJ394 (riquent, } \\
\text { abetimus sodium) } \\
{[131,132]}\end{array}$ & $\begin{array}{l}\text { Four dsDNA } \\
\text { helices coupled to } \\
\text { polyethylene scaffold }\end{array}$ & $\begin{array}{l}\text { Neutralizes anti-DNA } \\
\text { antibodies in serum and } \\
\text { tolerizes anti-DNA B cells }\end{array}$ & $\begin{array}{l}n=230 \text {, classes III to V lupus nephritis; } \\
\text { randomized, placebo-controlled, for } \\
76 \text { weeks }\end{array}$ & $\begin{array}{l}\text { Anti-DNA and complement profiles } \\
\text { improved with LP394, but no } \\
\text { significant difference in time to renal } \\
\text { flares between the two groups }\end{array}$ \\
\hline Rituximab [133] & $\begin{array}{l}\text { Chimeric antibody to } \\
\text { CD20 on B cells }\end{array}$ & $\begin{array}{l}\text { Agent targets and } \\
\text { silences or removes B cells } \\
\text { (some of which produce } \\
\text { autoantibodies) }\end{array}$ & $\begin{array}{l}n=10 \text { lupus nephritis patients, } \\
375 \mathrm{mg} / \mathrm{m}^{2}, 4 \text { weekly infusions, + oral } \\
\text { CS; duration } 12 \text { months }\end{array}$ & $\begin{array}{l}\text { 5/10 achieved complete remission } \\
\text { sustained for } 1 \text { year; } 3 / 10 \text { had partial } \\
\text { remission }\end{array}$ \\
\hline Epratuzumab [134] & $\begin{array}{l}\text { Humanized antibody } \\
\text { to CD22 on B cells }\end{array}$ & $\begin{array}{l}\text { Agent targets and } \\
\text { silences or removes B cells } \\
\text { (some of which produce } \\
\text { autoantibodies) }\end{array}$ & $\begin{array}{l}n=14 \text { ( } 4 \text { with nephritis); open-label } \\
\text { study. Four doses of } 360 \mathrm{mg} / \mathrm{m}^{2} \text { given } \\
\text { every } 2 \text { weeks; duration } 32 \text { weeks }\end{array}$ & $\begin{array}{l}\text { Total BILAG scores decreased by } \\
\geq 50 \% \text { in all } 14 \text { patients at some point } \\
\text { during the study. It was well tolerated }\end{array}$ \\
\hline $\begin{array}{l}\text { Belimumab } \\
\text { (lymphostat B) [135] }\end{array}$ & $\begin{array}{l}\text { Humanized antibody } \\
\text { to Blys (or BAFF) }\end{array}$ & $\begin{array}{l}\text { Agent blocks activation of } \\
B \text { cells by countering Blys } \\
\text { activation of B cells }\end{array}$ & $\begin{array}{l}n=449 \text { ( } 22 \text { to } 35 \% \text { with nephritis); } \\
\text { phase II randomized double-blind } \\
\text { placebo-controlled study. Patients } \\
\text { receive placebo or } 1,4 \text { or } 10 \mathrm{mg} / \mathrm{kg} \\
\text { belimumab at days } 0,14,28 \text { and then } \\
\text { every } 28 \text { days + standard-of-care } \\
\text { treatment; duration } 52 \text { weeks }\end{array}$ & $\begin{array}{l}\text { No significant differences in primary } \\
\text { end-points (reduction in SELENA- } \\
\text { SLEDAl scores or time to renal flares). } \\
\text { However, patients on belimumab } \\
\text { had significantly better physicians' } \\
\text { subjective assessment scores and } \\
\text { Short Form } 36 \text { scores) }\end{array}$ \\
\hline $\begin{array}{l}\text { Orencia (abatacept) } \\
\text { (www.clinical } \\
\text { trials.gov ID: } \\
\text { NCT00774852) }\end{array}$ & $\begin{array}{l}\text { Fusion protein of } \\
\text { CTLA4 linked to Fc } \\
\text { portion of human IgG }\end{array}$ & $\begin{array}{l}\text { Agent blocks T-cell:B-cell } \\
\text { cross-talk by blocking CD28- } \\
\text { CD80/CD86 interactions }\end{array}$ & $\begin{array}{l}n=100 ; \text { randomized, double-blind, } \\
\text { controlled, phase II multicenter } \\
\text { trial of CTLA4lg (abatacept) } \\
\text { plus cyclophosphamide vs. } \\
\text { cyclophosphamide alone in the } \\
\text { treatment of lupus nephritis }\end{array}$ & Currently recruiting \\
\hline $\begin{array}{l}\text { Rontalizumab } \\
\text { (www.clinical } \\
\text { trials.gov ID: } \\
\text { NCT00962832) }\end{array}$ & $\begin{array}{l}\text { Humanized antibody } \\
\text { to type } 1 \text { interferon }\end{array}$ & $\begin{array}{l}\text { Agent blocks the function } \\
\text { of the cytokine, interferon } \\
\text { type } 1\end{array}$ & $\begin{array}{l}n=210 \text {; phase II, randomized, } \\
\text { double-blind, placebo-controlled } \\
\text { study to evaluate the efficacy and } \\
\text { safety of rontalizumab in patients with } \\
\text { moderately to severely active systemic } \\
\text { lupus erythematosus }\end{array}$ & $\begin{array}{l}\text { Active: not recruiting patients at } \\
\text { present }\end{array}$ \\
\hline $\begin{array}{l}\text { MEDI-545 (www. } \\
\text { clinical trials.gov ID: } \\
\text { NCT00657189) }\end{array}$ & $\begin{array}{l}\text { Fully human antibody } \\
\text { to IFN-a }\end{array}$ & $\begin{array}{l}\text { Agent blocks the function } \\
\text { of the cytokine, interferon } \\
\text { type } 1\end{array}$ & $\begin{array}{l}n=80 \text {; phase } 2 \mathrm{~A} \text {, randomized, double- } \\
\text { blind, placebo-controlled, parallel- } \\
\text { dose study to evaluate the safety and } \\
\text { tolerability of multiple subcutaneous } \\
\text { doses of MEDI- } 545 \text {, in subjects with SLE }\end{array}$ & $\begin{array}{l}\text { Active: not recruiting patients at } \\
\text { present }\end{array}$ \\
\hline
\end{tabular}

BILAG, British Isles Lupus Assessment Group; CS, corticosteroids; SELENA, Safety of Estrogens in Lupus Erythematosus: National Assessment; SLE, systemic lupus erythematosus; SLEDAl, Systemic Lupus Erythematosus Disease Activity Index.

albeit being more toxic; hence, this treatment regime should be limited to 6 months and should only be given to patients with multiple poor prognostic factors [138].

\section{Intravenous immunoglobulin}

Intravenous immunoglobulin is another modality that has been tested. The efficacy of intravenous immunoglobulin in controlling disease activity and ameliorating classical disease manifestations ranges from 33 to 100\% in different case series surveyed in a recent meta-analysis [139]. Other analyses have documented similar positive results, with particular improvements in the clinical and histological readouts of nephritis [140]. Despite encouraging reports describing the efficacy of intravenous immunoglobulin therapy in SLE, most of the data are based on case reports and small series. Furthermore, the long-term efficacy, optimal dosage and duration of therapy of intravenous immunoglobulin in LN remain to be established. Nevertheless, intravenous immunoglobulin can be considered in patients with $\mathrm{LN}$ either as salvage immunotherapy in severe cases that are nonresponsive or nontolerant to conventional treatment or in patients who experience severe infectious complications.

\section{Calcineurin inhibitors}

Open-labeled uncontrolled studies have reported efficacy and tolerability of cyclosporin A in the treatment of PLN [141]. No published comparative trials between CYC and cyclosporin A in adult SLE patients are currently available. In an open study of 11 patients with LN, eight of whom were resistant or intolerant to CYC or AZA, significant improvement in proteinuria and anti-dsDNA titers was reported after treatment with cyclosporin A for 12 months [142].

\section{Immunoablative therapy}

Immunoablative therapy (that is, daily high doses of CYC followed by granulocyte colony-stimulating factor) 
followed by autologous hematopoietic stem cell transplantation is another option that can be entertained in severe refractory LN. Clinical remissions have been observed in about $65 \%$ of cases [143]. However, the relatively high incidence of toxicities and mortality remains a concern.

\section{Conclusion}

LN remains a major manifestation of SLE, as $60 \%$ of SLE patients may develop this end-organ involvement. The epidemiology and clinical manifestations of LN have been well studied over the past few decades. The 2003 addition to the ISN/RPS classification of the modified WHO schema of histological classification of LN has significantly improved how the disease is classified, managed and prognosticated. In terms of the underlying pathogenic mechanisms, we have gained significant insights regarding the cells and molecules that orchestrate the systemic as well as the target organ phases of the disease. How we manage LN has also evolved significantly over the past decade, thanks to multiple clinical trials. Currently, the optimal induction therapy appears to be i.v. $\mathrm{CYC}$ or oral mycophenolate, while maintenance is best achieved using oral mycophenolate, AZA or i.v. CYC. Newer targeted therapeutics built upon recent molecular insights are likely to revolutionize how LN is managed in the clinic in the coming years.

\section{Abbreviations}

AZA, azathioprine; BAFF, B-cell activating factor; CD40L, CD40 ligand;

CSF-1, colony-stimulating factor-1; CYC, cyclophosphamide; DC, dendritic cell; dsDNA, double-stranded DNA; ESRD, end-stage renal disease; GN, glomerulonephritis; IFN, interferon; IL, interleukin; ISN/RPS, International Society of Nephrology/Renal Pathology Society; i.v., intravenous; LN, lupus nephritis; MMF, mycophenolate mofetil; $\mathrm{NIH}$, National Institutes of Health PLN, proliferative lupus nephritis; RANTES, regulated upon activation, normal T-cell expressed and secreted; SLE, systemic lupus erythematosus; TGF $\beta$, transforming growth factor beta; TNF, tumor necrosis factor; WHO, World Health Organization.

\section{Competing interests}

The authors declare that they have no competing interests.

Published: 28 September 2011

\section{References}

1. Appel GB, Radhakrishnan J, D'Agati V: Secondary glomerular disease. In The Kidney. Edited by Brenner BM. 8th edition. Philadelphia, PA: Saunders; 2007:1067-1148.

2. Bertsias G, Gordon C, Boumpas DT: Clinical trials in SLE: lessons learned from the past as we proceed to the future - the EULAR recommendations for the management of SLE and the use of end-points in clinical trials. Lupus 2008, 17:437-442.

3. Mak A, Mok CC, Chu WP, To CH, Wong SN, Au TC: Renal damage in systemic lupus erythematosus: a comparative analysis of different age groups. Lupus 2007, 16:28-34.

4. Seligman VA, Lum RF, Olson JL, Li H, Criswell LA: Demographic differences in the outcome of SLE nephritis: a retrospective analysis. Am J Med 2002, $112: 726-729$

5. Cameron JS: Lupus nephritis. J Am Soc Nephrol 1999, 10:413-424.

6. Austin HA: Clinical evaluation and monitoring of systemic lupus erythematosis. Lupus 1998, 7:618-621.
7. McCluskey RT: Lupus nephritis. In Kidney Pathology Decennial 1966-1975. Edited by Sommers SC. East Norwalk, CT: Appleton-Century Crofts; 1975:435-450.

8. Austin HA, 3rd, Muenz LR, Joyce KM, Antonovych TT, Balow JE: Diffuse proliferative lupus nephritis: identification of specific pathologic features affecting renal outcome. Kidney Int 1984, 25:689-695.

9. Weening JJ, D'Agati VD, Schwartz MM: The classification of glomerulonephritis in systemic lupus erythematosis revisited. J Am SoC Nephrol 2004, 15:241-250.

10. Furness PN, Taub N: Interobserver reproducibility and application of the INS/RPS classification of lupus nephritis - a UK-wide study. Am J Surg Pathol 2006, 30:1030-1035.

11. Yokoyama H, Wada T, Hara A, Yamahana J, Nakaya I, Kobayashi M, Kitagawa, Kokubo KS, Iwata Y, Yoshimoto K, Shimizu K, Sakai N, Furuichi KT: The outcome and a new ISN/RPS 2003 classification of lupus nephritis in Japanese. Kidney Int 2004, 66:2382-2388.

12. Davidson A, Aranow C: Pathogenesis and treatment of systemic lupus erythematosus nephritis. Curr Opin Rheumatol 2006, 18:468-475.

13. Kanta $\mathrm{H}$, Mohan $\mathrm{C}$ : Murine lupus genes target 3 checkpoints in disease development - central tolerance in the adaptive immune system, peripheral amplification by innate immunity, and end-organ inflammation. Genes /mmun 2009, 10:390-396.

14. Hahn BH: Antibodies to DNA. N Engl J Med 1998, 338:1359-1368.

15. D’Agati VD, Appel GB, Estes D, Knowles DM, 2nd, Pirani CL: Monoclonal antibody identification of infiltrating mononuclear leukocytes in lupus nephritis. Kidney Int 1986, 30:573-581.

16. Díaz Gallo C, Jevnikar AM, Brennan DC, Florquin S, Pacheco-Silva A, Kelley VR Autoreactive kidney-infiltrating T-cell clones in murine lupus nephritis. Kidney Int 1992, 42:851-859.

17. Mukherjee R, Zhang Z, Zhong R, Yin ZQ, Roopenian DC, Jevnikar AM: Lupus nephritis in the absence of renal major histocompatibility complex class I and class II molecules. J Am Soc Nephrol 1996, 7:2445-2452.

18. Koh DR, Ho A, Rahemtulla A, Fung-Leung WP, Griesser H, MakTW: Murine lupus in MRL/lpr mice lacking CD4 or CD8 T cells. Eur J Immunol 1995, 25:2558-2562

19. Jabs DA, Burek CL, Hu Q, Kuppers RC, Lee B, Prendergast RA: Anti-CD4 monoclonal antibody therapy suppresses autoimmune disease in MRL/ Mp-Ipr/Ipr mice. Cell Immunol 1992, 141:496-507.

20. Jabs DA, Kuppers RC, Saboori AM, Burek CL, Enger C, Lee B, Prendergast RA: Effects of early and late treatment with anti-CD4 monoclonal antibody on autoimmune disease in MRL/MP-Ipr/Ipr mice. Cell Immunol 1994, 154:66-76.

21. Radeke HH, Tschernig T, Karulin A, Schumm G, Emancipator SN, Resch K, Tary-Lehmann M: CD4 ${ }^{+} \mathrm{T}$ cells recognizing specific antigen deposited in glomeruli cause glomerulonephritis-like kidney injury. Clin Immunol 2002. 104:161-173.

22. Desai-Mehta A, Lu L, Ramsey-Goldman R, Datta SK: Hyperexpression of CD40 ligand by $B$ and T cells in human lupus and its role in pathogenic autoantibody production. J Clin Invest 1996, 97:2063-2073.

23. Koshy M, Berge D, Crow MK: Increased expression of CD40 ligand on systemic lupus erythematosus lymphocytes. J Clin Invest 1996, 98:826-837.

24. Devi BS, Van Noordin S, Krausz T, Davies KA: Peripheral blood lymphocytes in SLE - hyperexpression of CD154 on T and B lymphocytes and increased number of double negative T cells. J Autoimmun 1998, 11:471-475.

25. Kalled SL, Cutler AH, Datta SK, Thomas DW: Anti-CD40 ligand antibody treatment of SNF1 mice with established nephritis: preservation of kidney function. J Immunol 1998, 160:2158-2165.

26. Wang $X$, Huang W, Schiffer LE, Mihara M, Akkerman A, Hiromatsu K, Davidson A: Effects of anti-CD154 treatment on B cells in murine systemic lupus erythematosus. Arthritis Rheum 2003, 48:495-506.

27. Alderson MR, Armitage RJ, Tough TW, Strockbine L, Fanslow WC, Spriggs MK: CD40 expression by human monocytes: regulation by cytokines and activation of monocytes by the ligand for CD40. J Exp Med 1993, 178:669-674.

28. Caux C, Massacrier C, Vanbervliet B, Dubois B, van Kooten C, Durand I, Banchereau J: Activation of human dendritic cells through CD40 crosslinking. J Exp Med 1994, 180:1263-1272.

29. Yellin MJ, D'Agati V, Parkinson G, Han AS, Szema A, Baum D, Estes D, Szabolcs $M$, Chess L: Immunohistologic analysis of renal CD40 and CD40L expression in lupus nephritis and other glomerulonephritides. Arthritis Rheum 1997, 40:124-134.

30. Kuroiwa T, Schlimgen R, Illei GG, McInnes IB, Boumpas DT: Distinct T cell/ 
renal tubular epithelial cell interactions define differential chemokine production: implications for tubulointerstitial injury in chronic glomerulonephritides. J Immunol 2000, 164:3323-3329.

31. van Kooten C, Gerritsma JS, Paape ME, van Es LA, Banchereau J, Daha MR: Possible role for CD40-CD40L in the regulation of interstitial infiltration in the kidney. Kidney Int 1997, 51:711-721.

32. Uhm WS, Na K, Song GW, Jung SS, Lee T, Park MH, Yoo DH: Cytokine balance in kidney tissue from lupus nephritis patients. Rheumatology (Oxford) 2003, 42:935-938.

33. Calvani N, Richards HB, Tucci M, Pannarale G, Silvestris F: Up-regulation of IL-18 and predominance of a Th1 immune response is a hallmark of lupus nephritis. Clin Exp Immunol 2004, 138:171-178.

34. Masutani K, Akahoshi M, Tsuruya K, Tokumoto M, Ninomiya T, Kohsaka T, Fukuda K, Kanai H, Nakashima H, Otsuka T, Hirakata H: Predominance of Th1 immune response in diffuse proliferative lupus nephritis. Arthritis Rheum 2001, 44:2097-2106.

35. Tucci M, Lombardi L, Richards HB, Dammacco F, Silvestris F: Overexpression of interleukin-12 and Thelper 1 predominance in lupus nephritis. Clin Exp Immunol 2008, 154:247-254.

36. Chan RW, Tam LS, Li EK, Lai FM, Chow KM, Lai KB, Li PK, Szeto CC: Inflammatory cytokine gene expression in the urinary sediment of patients with lupus nephritis. Arthritis Rheum 2003, 48:1326-1331.

37. Jacob CO, van der Meide PH, McDevitt HO: In vivo treatment of (NZB x NZW) F1 lupus-like nephritis with monoclonal antibody to gamma interferon. J Exp Med 1987, 166:798-803.

38. Peng SL, Moslehi J, Craft J: Roles of interferon-gamma and interleukin-4 in murine lupus. J Clin Invest 1997, 99:1936-1946.

39. Balomenos D, Rumold R, Theoilopoulos AN: Interferon- $\gamma$ is required for lupus-like disease and lymphoaccumulation in MRL-Ipr mice. J Clin Invest 1998, 101:364-371.

40. Bossù P, Neumann D, Del Giudice E, Ciaramella A, Gloaguen I, Fantuzzi G, Dinarello CA, Di Carlo E, Musiani P, Meroni PL, Caselli G, Ruggiero P, Boraschi D: IL-18 CDNA vaccination protects mice from spontaneous lupus-like autoimmune disease. Proc Natl Acad Sci U S A 2003, 100:14181-14816.

41. Nakajima A, Hirose S, Yagita H, Okumura K: Roles of IL-4 and IL-12 in the development of lupus in NZB/W F1 mice. J Immunol 1997, 158:1466-1472.

42. Rüger BM, Erb KJ, He Y, Lane JM, Davis PF, Hasan Q: Interleukin-4 transgenic mice develop glomerulosclerosis independent of immunoglobulin deposition. Eur I Immunol 2000, 30:2698-2703.

43. Singh RR, Saxena V, Zang S, Li L, Finkelman FD, Witte DP, Jacob CO: Differential contribution of IL-4 and STAT6 vs. STAT4 to the development of lupus nephritis. J Immunol 2003, 170:4818-4825.

44. Singh RR: IL-4 and many roads to lupuslike autoimmunity. Clin Immunol 2003, 108:73-79

45. Woltman AM, de Fijter JW, Zuidwijk K, Vlug AG, Bajema IM, van der Kooij SW, van Ham V van Kooten C: Ouantification of dendritic cell subsets in human renal tissue under normal and pathological conditions. Kidney Int 2007, 71:1001-1008

46. Krüger T, Benke D, Eitner F, Lang A, Wirtz M, Hamilton-Williams EE, Engel D, Giese B, Müller-Newen G, Floege J, Kurts C: Identification and functional characterization of dendritic cells in the healthy murine kidney and in experimental glomerulonephritis. J Am Soc Nephrol 2004, 15:613-621.

47. Soos TJ, Sims TN, Barisoni L, Lin K, Littman DR, Dustin ML, Nelson PJ: CX(3) CR1(+) interstitial dendritic cells form a contiguous network throughout the entire kidney. Kidney Int 2006, 70:591-596.

48. Fiore N, Castellano G, Blasi A, Capobianco C, Loverre A, Montinaro V, Netti S, Torres D, Manno C, Grandaliano G, Ranieri E, Schena FP, Gesualdo L: Immature myeloid and plasmacytoid dendritic cells infiltrate renal tubulointerstitium in patients with lupus nephritis. Mol /mmuno/ 2008, 45:259-265

49. Tucci M, Quatraro C, Lombardi L, Pellegrino C, Dammacco F, Silvestris F: Glomerular accumulation of plasmacytoid dendritic cells in active lupus nephritis: role of interleukin-18. Arthritis Rheum 2008, 58:251-262.

50. Cederblad B, Blomberg S, Vallin H, Perers A, Alm GV, Rönnblom L: Patients with systemic lupus erythematosus have reduced numbers of circulating natural interferon-alpha-producing cells. J Autoimmun 1998, 11:465-470

51. Gill MA, Blanco P, Arce E, Pascual V, Banchereau J, Palucka AK: Blood dendritic cells and DC-poietins in systemic lupus erythematosus. Hum Immunol 2002, 63:1172-1180

52. Farkas L, Beiske K, Lund-Johansen F, Brandtzaeg P, Jahnsen FL: Plasmacytoid dendritic cells (natural interferon-alpha/beta-producing cells) accumulate in cutaneous lupus erythematosus lesions. Am J Pathol 2001, 159:237-243.

53. Bagavant H, Deshmukh US, Wang H, LyT, Fu SM: Role for nephritogenic T cells in lupus glomerulonephritis: progression to renal failure is accompanied by T cell activation and expansion in regional lymph nodes. J Immunol 2006, 177:8258-8265.

54. Schiffer L, Bethunaickan R, Ramanujam M, Huang W, Schiffer M, Tao H, Madaio MP, Bottinger EP, Davidson A: Activated renal macrophages are markers of disease onset and disease remission in lupus nephritis. J Immunol 2008, 180:1938-1947.

55. Fujinaka H, Nameta M, Kovalenko P, Matsuki A, Kato N, Nishimoto G, Yoshida Y, Yaoita E, Naito M, Kihara I, Tomizawa S, Yamamoto T: Periglomerular accumulation of dendritic cells in rat crescentic glomerulonephritis. J Nephrol 2007, 20:357-363.

56. Scholz J, Lukacs-Kornek V, Engel DR, Specht S, Kiss E, Eitner F, Floege J, Groene $\mathrm{HJ}$, Kurts C: Renal dendritic cells stimulate IL-10 production and attenuate nephrotoxic nephritis. J Am Soc Nephrol 2008,19:527-537.

57. Monrad S, Kaplan MJ: Dendritic cells and the immunopathogenesis of systemic lupus erythematosus. Immunol Res 2007, 37:135-145.

58. Coates PT, Colvin BL, Ranganathan A, Duncan FJ, Lan YY, Shufesky WJ, Zahorchak AF, Morelli AE, Thomson AW: CCR and CC chemokine expression in relation to Flt3 ligand-induced renal dendritic cell mobilization. Kidney Int 2004, 66:1907-1917.

59. Castellino F, Huang AY, Altan-Bonnet G, Stoll S, Scheinecker C, Germain RN: Chemokines enhance immunity by guiding naive $C D 8^{+} T$ cells to sites of CD4 ${ }^{+} T$ cell-dendritic cell interaction. Nature 2006, 440:890-895.

60. Tucci M, Calvani N, Richards HB, Quatraro C, Silvestris F: The interplay of chemokines and dendritic cells in the pathogenesis of lupus nephritis. Ann N Y Acad Sci 2005, 1051:421-432

61. Hooke DH, Gee DC, Atkins RC: Leukocyte analysis using monoclonal antibodies in human glomerulonephritis. Kidney Int 1987, 31:964-972.

62. Alexopoulos E, Seron D, Hartley RB, Cameron JS: Lupus nephritis: correlation of interstitial cells with glomerular function. Kidney Int 1990, 37:100-109.

63. Kootstra CJ, Sutmuller M, Baelde HJ, de Heer E, Bruiin JA: Association between leukocyte infiltration and development of glomerulosclerosis in experimental lupus nephritis. J Pathol 1998, 184:219-225.

64. Lan HY, Nikolic-Paterson DJ, Mu W, Atkins RC: Local macrophage proliferation in the pathogenesis of glomerular crescent formation in rat anti-glomerular basement membrane (GBM) glomerulonephritis. Clin Exp Immunol 1997, 110:233-240.

65. Holdsworth SR, Neale TJ, Wilson CB: Abrogation of macrophage-dependent injury in experimental glomerulonephritis in the rabbit. Use of an antimacrophage serum. J Clin Invest 1981, 68:686-698.

66. Duffield JS, Tipping PG, Kipari T, Cailhier JF, Clay S, Lang R, Bonventre JV, Hughes J: Conditional ablation of macrophages halts progression of crescentic glomerulonephritis. Am J Pathol 2005, 167:1207-1219.

67. Ikezumi Y, Hurst LA, Masaki T, Atkins RC, Nikolic-Paterson DJ: Adoptive transfer studies demonstrate that macrophages can induce proteinuria and mesangial cell proliferation. Kidney Int 2003, 63:83-95.

68. Holdsworth SR, Neale TJ: Macrophage-induced glomerular injury. Cell transfer studies in passive autologous antiglomerular basement membrane antibody-initiated experimental glomerulonephritis. Lab Invest 1984, 51:172-180.

69. Tipping PG, Timoshanko J: Contributions of intrinsic renal cells to crescentic glomerulonephritis. Nephron Exp Nephrol 2005, 101:e173-e178.

70. Timoshanko JR, Tipping PG: Resident kidney cells and their involvement in glomerulonephritis. Curr Drug Targets Inflamm Allergy 2005, 4:353-362.

71. Li S, Kurts C, Kontgen F, Holdsworth SR, Tipping PG: Major histocompatibility complex class II expression by intrinsic renal cells is required for crescentic glomerulonephritis. J Exp Med 1998, 188:597-602.

72. Molano A, Lakhani P, Aran A, Burkly LC, Michaelson JS, Putterman C: TWEAK stimulation of kidney resident cells in the pathogenesis of graft versus host induced lupus nephritis. Immunol Lett 2009, 125:119-128.

73. Timoshanko JR, Sedgwick JD, Holdsworth SR, Tipping PG: Intrinsic renal cells are the major source of tumor necrosis factor contributing to renal injury in murine crescentic glomerulonephritis. J Am Soc Nephrol 2003, 14:1785-1793.

74. Ka SM, Cheng CW, Shui HA, Wu WM, Chang DM, Lin YC, Chen A: Mesangial cells of lupus-prone mice are sensitive to chemokine production. Arthritis Res Ther 2007, 9:R67.

75. Reilly CM, Oates JC, Cook JA, Morrow JD, Halushka PV, Gilkeson GS: Inhibition of mesangial cell nitric oxide in MRL/lpr mice by prostaglandin $\mathrm{J} 2$ and 
proliferator activation receptor-gamma agonists. J Immuno/ 2000, 164:1498-1504.

76. Reilly CM, Oates JC, Sudian J, Crosby MB, Halushka PV, Gilkeson GS: Prostaglandin J(2) inhibition of mesangial cell iNOS expression. Clin Immunol 2001, 98:337-345.

77. Crispín JC, Oukka M, Bayliss G, Cohen RA, Van Beek CA, Stillman IE, Kyttaris VC, Juang YT, Tsokos GC: Expanded double negative T cells in patients with systemic lupus erythematosus produce IL-17 and infiltrate the kidneys. J Immunol 2008, 181:8761-8766.

78. Kang HK, Liu M, Datta SK: Low-dose peptide tolerance therapy of lupus generates plasmacytoid dendritic cells that cause expansion of autoantigen-specific regulatory $T$ cells and contraction of inflammatory Th17 cells. J Immuno/ 2007, 178:7849-7858.

79. Bennett L, Palucka AK, Arce E, Cantrell V, Borvak J, Banchereau J, Pascual V: Interferon and granulopoiesis signatures in systemic lupus erythematosus blood. J Exp Med 2003, 197:711-723.

80. Baechler EC, Batliwalla FM, Karypis G, Gaffney PM, Ortmann WA, Espe KJ Shark KB, Grande WJ, Hughes KM, Kapur V, Gregersen PK, Behrens TW: Interferon-inducible gene expression signature in peripheral blood cells of patients with severe lupus. Proc Natl Acad Sci US A 2003, 100:2610-2615.

81. Kirou KA, Lee C, George S, Louca K, Papagiannis IG, Peterson MG, Ly N, Woodward RN, Fry KE, Lau AY, Prentice JG, Wohlgemuth JG, Crow MK: Coordinate overexpression of interferon-alpha induced genes in systemic lupus erythematosus. Arthritis Rheum 2004, 50:3958-3967.

82. Fairhurst AM, Xie C, Fu YY, Wang A, Boudreaux CD, Zhou XJ, Cibotti R, Coyle A, Connolly JE, Wakeland EK, Mohan C: Type I interferons produced by resident renal cells may promote end-organ disease in autoantibodymediated glomerulonephritis. J Immuno/ 2009, 183:6831-6838.

83. Border WA, Ruoslahti E: Transforming growth factor beta in disease: the dark side of tissue repair. J Clin Invest 1992, 90:1-7.

84. Nakamura T, Ebihara I, Shirato I, Tomino Y, Koide H: Increased steady-state levels of mRNA coding for extracellular matrix components in kidneys of NZB/W F1 mice. Am J Pathol 1991, 139:437-450.

85. Nakamura T, Ebihara I, Nagaoka I, Osada S, Tomino Y, Koide H: Effect of methylprednisolone on transforming growth factor-beta, insulin-like growth factor-I, and basic fibroblast growth factor gene expression in the kidneys of NZB/W F1 mice. Ren Physiol Biochem 1993, 16:105-116.

86. Taniguchi Y, Yorioka N, Masaki T, Yamashita K, Ito T, Ueda H, Yamakido M: Role of transforming growth factor-beta 1 in glomerulonephritis. J Int Med Res 1997, 25:71-80.

87. Saxena V, Lienesch DW, Zhou M, Bommireddy R, Azhar M, Doetschman T, Singh RR: Dual roles of immunoregulatory cytokine TGF- $\beta$ in the pathogenesis of autoimmunity-mediated organ damage. J /mmuno/ 2008, 180:1903-1912.

88. Bloom RD, Florquin S, Singer GG, Brennan DC, Kelley VR: Colony stimulating factor-1 in the induction of lupus nephritis. Kidney Int 1993, 143:1000-1009.

89. Isbel NM, Hill PA, Foti R, Mu W, Hurst LA, Stambe C, Lan HY, Atkins RC, NikolicPaterson DJ: Tubules are the major site of M-CSF production in experimental kidney disease: correlation with local macrophage proliferation. Kidney Int 2001, 60:614-625.

90. Yui MA, Brissette WH, Brennan DC, Wuthrich RP, Rubin-Kelley VE: Increased macrophage colony-stimulating factor in neonatal and adult autoimmune MRL-Ipr mice. Am J Pathol 1991, 139:255-261.

91. Naito T, Yokoyama H, Moore KJ, Dranoff G, Mulligan RC, Kelley VR: Macrophage growth factors introduced into the kidney initiate renal injury. Mol Med 1996, 2:297-312

92. Lan HY, Yang N, Nikolic-Paterson DJ, Yu XQ, Mu W, Isbel NM, Metz CN, Bucala $R$, Atkins RC: Expression of macrophage migration inhibitory factor in human glomerulonephritis. Kidney Int 2000, 57:499-509.

93. Lan HY, Mu W, Yang N, Meinhardt A, Nikolic-Paterson DJ, Ng YY, Bacher M Atkins RC, Bucala R: De novo renal expression of macrophage migration inhibitory factor during the development of rat crescentic glomerulonephritis. Am J Pathol 1996, 149:1119-1127.

94. Otukesh H, Chalian M, Hoseini R, Chalian H, Hooman N, Bedayat A, Yazdi RS, Sabaghi S, Mahdavi S: Urine macrophage migration inhibitory factor in pediatric systemic lupus erythematosus. Clin Rheumatol 2007, 26:2105-2107.

95. Hoi AY, Hickey MJ, Hall P, Yamana J, O'Sullivan KM, Santos LL, James WG, Kitching AR, Morand EF: Macrophage migration inhibitory factor deficiency attenuates macrophage recruitment, glomerulonephritis, and lethality in MRL/Ipr mice. J Immuno/ 2006, 177:5687-5696.
96. Sasaki S, Nishihira J, Ishibashi T, Yamasaki Y, Obikane K, Echigoya M, Sado Y, Ninomiya Y, Kobayashi K: Transgene of MIF induces podocyte injury and progressive mesangial sclerosis in the mouse kidney. Kidney Int 2004, 65:469-481.

97. Yang N, Nikolic-Patersonm DJ, Ng YY, Mu W, Metz C, Bacher M, Meinhardt A, Bucala R, Atkins RC, Lan HY: Reversal of established rat crescentic glomerulonephritis by blockade of macrophage migration inhibitory factor (MIF): potential role of MIF in regulating glucocorticoid production. Mol Med 1998, 4:413-424

98. Lan HY, Bacher M, Yang N, Mu W, Nikolic-Paterson DJ, Metz C, Meinhardt A, Bucala R, Atkins RC: The pathogenic role of macrophage migration inhibitory factor in immunologically induced kidney disease in the rat. J Exp Med 1997, 185:1455-1465.

99. Fu Y, Du Y, Mohan C: Experimental anti-GBM disease as a tool for studying spontaneous lupus nephritis. Clin Immunol 2007, 124:109-118.

100. Zoja C, Liu XH, Donadelli R, Abbate M, Testa D, Corna D, Taraboletti G, Vecchi A, Dong QG, Rollins BJ, Bertani T, Remuzzi G: Renal expression of monocyte chemoattractant protein-1 in lupus autoimmune mice. J Am Soc Nephrol 1997, 8:720-729.

101. Pérez de Lema G, Maier H, Nieto E, Vielhauer V, Luckow B, Mampaso F, Schlöndorff D: Chemokine expression precedes inflammatory cell infiltration and chemokine receptor and cytokine expression during the initiation of murine lupus nephritis. J Am Soc Nephro/ 2001, 12:1369-1382.

102. Marks SD, Williams SJ, Tullus K, Sebire NJ: Glomerular expression of monocyte chemoattractant protein-1 is predictive of poor renal prognosis in pediatric lupus nephritis. Nephrol Dial Transplant 2008, 23:3521-3526.

103. Chan RW, Lai FM, Li EK, Tam LS, Chow KM, Lai KB, Li PK, Szeto CC: Intrarenal cytokine gene expression in lupus nephritis. Ann Rheum Dis 2007, 66:886-892.

104. Noris M, Bernasconi S, Casiraghi F, Sozzani S, Gotti E, Remuzzi G, Mantovani A: Monocyte chemoattractant protein-1 is excreted in excessive amounts in the urine of patients with lupus nephritis. Lab Invest 1995, 73:804-809.

105. Wada T, Yokoyama H, Su SB, Mukaida N, Iwano M, Dohi K, Takahashi Y, Sasaki T, Furuichi K, Segawa C, Hisada Y, Ohta S, Takasawa K, Kobayashi K, Matsushima K: Monitoring urinary levels of monocyte chemotactic and activating factor reflects disease activity of lupus nephritis. Kidney Int 1996, 49:761-767.

106. Lu B, Rutledge BJ, Gu L, Fiorillo J, Lukacs NW, Kunkel SL, North R, Gerard C, Rollins BJ: Abnormalities in monocyte recruitment and cytokine expression in monocyte chemoattractant protein 1-deficient mice. J Exp Med 1998, 187:601-608

107. Hasegawa H, Kohno M, Sasaki M, Inoue A, Ito MR, Terada M, Hieshima K, Maruyama H, Miyazaki J, Yoshie O, Nose M, Fujita S: Antagonist of monocyte chemoattractant protein 1 ameliorates the initiation and progression of lupus nephritis and renal vasculitis in MRL/Ipr mice. Arthritis Rheum 2003, 48:2555-2566.

108. Shimizu S, Nakashima H, Masutani K, Inoue Y, Miyake K, Akahoshi M, Tanaka Y, Egashira K, Hirakata H, Otsuka T, Harada M: Anti-monocyte chemoattractant protein-1 gene therapy attenuates nephritis in MRL/lpr mice. Rheumatology (Oxford) 2004, 43:1121-1128.

109. Shimizu S, Nakashima H, Karube K, Ohshima K, Egashira K: Monocyte chemoattractant protein-1 activates a regional Th1 immunoresponse in nephritis of MRL/Ipr mice. Clin Exp Rheumato/ 2005, 23:239-242.

110. Anders HJ, Belemezova E, Eis V, Segerer S, Vielhauer V, Perez de Lema G, Kretzler M, Cohen CD, Frink M, Horuk R, Hudkins KL, Alpers CE, Mampaso F, Schlöndorff D: Late onset of treatment with a chemokine receptor CCR1 antagonist prevents progression of lupus nephritis in MRL-Fas(lpr) mice. J Am Soc Nephrol 2004, 15:1504-1513.

111. Chong BF, Mohan C: Targeting the CXCR4/CXCL12 axis in systemic lupus erythematosus. Expert Opin Ther Targets 2009, 13:1147-1153.

112. Wang A, Fairhurst AM, Tus K, Subramanian S, Liu Y, Lin F, Igarashi P, Zhou XJ, Batteux F, Wong D, Wakeland EK, Mohan C: CXCR4/CXCL12 hyperexpression plays a pivotal role in the pathogenesis of lupus. J Immunol 2009, 182:4448-4458.

113. Balabanian K, Couderc J, Bouchet-Delbos L, Amara A, Berrebi D, Foussat A, Baleux F, Portier A, Durand-Gasselin I, Coffman RL, Galanaud P, Peuchmaur M, Emilie D: Role of the chemokine stromal cell-derived factor 1 in autoantibody production and nephritis in murine lupus. J Immuno/ 2003, 170:3392-3400.

114. Pollak VE, Pirani CL, Schwartz FD: The natural history of the renal manifestations of systemic lupus erythematosis. J Lab Clin Med 1964 
63:537-550

115. Fiehn C, Hajjar Y, Mueller K. Improved clinical outcome of lupus nephritis during the past decade: importance of early diagnosis and treatment. Ann Rheum Dis 2003, 62:435-439.

116. Austin HA, 3rd, Boumpas DT, Vaughan EM, Balow JE. Highrisk features of lupus nephritis: importance of race and clinical and histological factors in 166 patients. Nephrol Dial Transplant 1995, 10:1620-1628.

117. Lupus nephritis: prognostic factors and probability of maintaining lifesupporting renal function 10 years after the diagnosis. Gruppo Italiano per lo Studio della Nefrite Lupica (GISNEL). Am J Kidney Dis 1992, 19:473-479.

118. Austin HA, 3rd, Kilppel JH, Balow JE. Therapy of lupus nephritis. Controlled trail of prednisone and cytotoxic drugs. N Engl J Med 1986, 10:614-619.

119. Gourley MF, Austin HA, 3rd, Scott D, Yarboro CH, Vaughan EM, Muir J, Boumpas DT, Klippel JH, Balow JE, Steinberg AD. Methylprednisolone and cyclophosphamide, alone or in combination, in patients with lupus nephritis. A randomized controlled trial. Ann Int Med 1996, 125:549-557.

120. Bono L, Cameron JS, Hicks JA: The very long-term prognosis and complications of lupus nephritis and its treatment. QJM 1999, 92:211-218

121. Houssiau FA, Vasconcelos C, D'Cruz D, Sebastiani GD, de Ramon Garrido E, Danieli MG, Abramovicz D, Blockmans D, Mathieu A, Direskeneli H, Galeazzi M, Gul A, Levy Y, Petera P, Popovic R, Petrovic R, Sinico RA, Cattaneo R, Font Depresseux G, Cosyns JP, Cervera R: Immunosuppressive therapy in lupus nephritis: the Euro-Lupus Nephritis Trial, a randomized trial of low-dose versus high-dose intravenous cyclophosphamide. Arthritis Rheum 2002, 46:2121-2131.

122. Allison AC, Eugui EM: Mycophenolate mofetil and its mechanisms of action. Immunopharmacology 2000, 47:85-118,

123. Chan TM, Li FK, Tang CSO, Wong RWS, Fang GX, Ji, YL, Lau CS, Wong AKM, Tong MKL, Chan KW, Lai KN: Efficacy of mycophenolate mofetil in patients with diffuse proliferative lupus nephritis. N Engl J Med 2000, 343:1 156-1162.

124. Ginzler EM, Dooley MA, Aranow C: Mycophenolate mofetil or IV cyclophosphamide for lupus nephritis. N Engl J Med 2005, 353:2219-2228.

125. Appel GB, Contreras G, Dooley MA: Mycophenolate mofetil versus cyclophosphamide for induction treatment of lupus nephritis. J Am Soc Nephrol 2009, 20:1103-1116.

126. Contreras H, Sosnov J: Role of mycophenolate mofetil in the treatment of lupus nephritis. Clin J Am Soc Nephrol 2007, 2:879-890.

127. Houssiau FA, D'Cruz D, Sangle S, Remy P, Vasconcelos C, Petrovic R, Fiehn C, Garrido ER, Gilboe I-M, Tektonidou M, Blockmans D, Ravelingien I, Guern V, Depresseux G, Guillevin L, Ricard Cervera R, the MAINTAIN Nephritis Trial Group: Azathioprine versus mycophenolate mofetil for long-term immunosuppression in lupus nephritis: results from the MAINTAIN Nephritis Trial. Ann Rheum Dis 2010, 69:2083-2089.

128. Roman MJ, Shanker BA, Davis A: Prevalence and correlates of accelerated atherosclerosis in systemic lupus erythematosis. N Eng/ J Med 2003, 349:2399-2406.

129. Bruce IN, Urowitz MB, Gladman DD: Risk factors for coronary heart disease in women with systemic lupus erythematosis: the Toronto Risk Factor Study. Arthritis Rheum 2003, 48:3159-3167.

130. Houssiau FA, Lefevre C, Depresseaux G, Lambert M, Devogelaer JP, Nagant de Deuxchaisnes: Trabecular and cortical bone loss in systemic lupus erythematosis. Br J Rheum 1996, 35:244-247.
131. Jones DS, Barstad PA, Field MJ, Hachmann JP, Hayag MS, Hill KW, Iverson GM, Livingston DA, Palanki MS: Immunospecific reduction of antioligonucleotide antibody-forming cells with a tetrakisoligonucleotide conjugate (LJP 394), a therapeutic candidate for the treatment of lupus nephritis. J Med Chem 1995, 38:2138-2144.

132. Alarcon-Segovia D, Tumlin JA, Furie RA: LJP 394 for the prevention of renal flare in patients with systemic lupus erythematosis: results from a randomized, double-blind, placebo-controlled study. Arthritis Rheum 2003, 48:442-454.

133 Sfikakis PP, Boletis JN, Lionaki S: Remission of proliferative lupus nephritis following B call depletion therapy is preceded by down-regulation of the T cell costimulatory molecule CD40 ligand: an open-label trial. Arthritis Rheum 2005, 52:501-513.

134. Dörner T, Kaufmann J, Wegener WA, Teoh N, Goldenberg DM, Burmester GR: Initial clinical trial of epratuzumab (humanized anti-CD22antibody) for immunotherapy of systemic lupus erythematosus. Arthritis Res Ther 2006 8:R74. doi:10.1186/ar1942.

135. Wallace DJ, StohI W, Furie RA, Lisse JR, Mckay JD, Merrill JT, Petri MA, Ginzler EM, Chatham WW, Mccune WJ, Fernandez V, Chevrier MR, Zhong ZJ, Freimuth WW: A phase II, randomized, double-blind, placebo-controlled, doseranging study of belimumab in patients with active systemic lupus erythematosus. Arthritis Rheum 2009, 61:1168-1178

136. Austin HA III, Boumpas DT, Vaughan EM: Predicting renal outcomes in severe lupus nephritis: contributions of clinical and histologic data. Kidney Int 1994, 45:544-550

137. Barr RG, Seliger S, Appel GB: Prognosis in proliferative status and race/ ethnicity. Nephrol Dial Transplant 2003, 18:2039-2046.

138. Mok CC, Ying KY, Ng WL, Lee KW, To CH, Lau CS, Wong RWS, Au TK: Longterm outcome of diffuse proliferative lupus glomerulonephritis treated with cyclophosphamide. Am J Med 2006, 119:355e25-355e33.

139. Zandman-Goddard G, Levy Y, Shoenfeld Y: Intravenous immunoglobulin therapy and systemic lupus erythematosis. Clin Rev Allergy Immunol 2005, 29:219-228.

140. Boletis JN, Loannidis JP, Boki KA, Moutsopoulos HM: Intravenous immunoglobulin compared with clyclophosphamide for proliferative lupus nephritis. Lancet 1999, 354:569-570.

141. Tam LS, Li EK, Leung CB, Wong KC, Lai FM, Wang A, Szeto CC, Lui SF: Longterm treatment of lupus nephritis with cyclosporin A. QJM 1998, 91:573-580.

142. Dostal C, Tesar V, Rychlik I, Zabka J, Vencovsky J, Bartunkova J, Stejskalova A Tegzova D: Effect of 1 year of cyclosporine A treatment on the activity and renal involvement of systemic lupus erythematosis: a pilot study. Lupus 1998, 7:29-36.

143. Jayne D, Passweg J, Marmont A: Autologous stem cell transplantation for systemic lupus erythematosis. Lupus 2004, 13:168-176.

doi:10.1186/ar3378

Cite this article as: Saxena R, et al:: Lupus nephritis: current update. Arthritis Research \& Therapy 2011, 13:240. 